\title{
ALTERATIONS IN PEAK TORQUE OCCUR WITHOUT HEMATOLOGICAL CHANGES AFTER MUSCLE FATIGUE
}

\author{
AS ALTERAÇÕES NO PICO DE TORQUE OCORREM SEM MODIFICAÇÕES EM PARÂMETROS \\ HEMATOLÓGICOS APÓS FADIGAMUSCULAR
}

Original Article

ARTIGO ORIGINAL

Artículo Original

\section{LOS CAMBIOS EN EL PICO DE PAR OCURREN SIN MODIFICACIONES EN PARÁMETROS HEMATOLÓGICOS DESPUÉSDEFATIGA MUSCULAR}

Frank Shiguemitsu Suzuki (Physical Education Professional) Marcelo Martins Kalytczak² (Physical Education Professional)

Rodrigo Augusto Ferreira

Palomares

(Physical Education Professional)

Marcos Rodolfo Paunksnis ${ }^{1}$

(Physical Education Profissional)

Sergio Matias Silva

(Physical Education Professional)

Fabiano Politi

(Physiotherapist)

Adriana Jaime Sbampato 3

(Biologist)

Andrey Jorge Serra ${ }^{2}$

(Physical Education Professional)

Alexandre Lopes Evangelista ${ }^{3}$

(Physical Education Professional)

Angélica Castilho Alonso ${ }^{1}$

(Physiotherapist)

Aylton Figueira Junior

(Physical Education Professional)

Duncan Buchan 4

(Physical Education Professional)

Julien Steven Baker ${ }^{4}$

(Physical Education Professional)

Danilo Sales Bocalini

(Physical Education Professional)

1. Universidade São Judas Tadeu

(USJT), Programa de Pos-Graduação

em Educação Física e Ciências do

Envelhecimento. Laboratório de

Fisiologia Translacional,

São Paulo, Brazil.

2. Universidade Nove de Julho

(UNINOVE), Programa de Pos-

Graduação em Ciências da

Reabilitação e Biofotônica Aplicada

a Ciências da Saúde São Paulo, Brazil.

3. Universidade Nove de Julho

(UNINOVE), Departamento de

Educação Física, São Paulo, Brazil.

4. Institute of Clinical Exercise

and Health Science. University of

the West of Scotland, Hamilton,

Lanarkshire, Scotland.

\section{Correspondence:}

Danilo Sales Bocalini

Rua Ary Barroso, 68, apto 105,

Torre 1, Ferrazópolis, São Bernardo

do Campo, São Paulo, Brazil.

09790-240. bocaliniht@hotmail.com

\begin{abstract}
Introduction: Muscular fatigue during voluntary muscle contractions is a complex and multifactorial phenomenon associated with central changes and adaptations of the neuromuscular system. Objective: The aim of this study was to analyze the changes in both peak torque and hematological parameters in active and inactive healthy subjects following a muscular fatigue protocol. Methods: Twenty-one healthy adult males performed a muscle fatigue protocol (10 sets, 10 repetitions of knee extension at $75 \%$ of the maximal isometric torque (MIT), $120^{\text {os-1 }}$ and 40 seconds of rest). Hematocrit (Ht), red blood cells (RBC) and leukocytes (L) analysis were evaluated before (B) and after (A) a fatigue test. Results: The inactive group presented impairment only in concentric muscular action of $-41 \pm 4 \%$ in relation to the active $(-23 \pm 3 \%)$ group. No differences were found in hematological parameters in inactive group ( $H \mathrm{t}, \mathrm{B}: 45.00 \pm 0.01$ vs. A: $47.00 \pm 0.01$; RBC, B: $442 \pm 40$ vs. A: $487 \pm 41$; $L, B: 7,565 \pm 2,878$ vs. $A: 8,015 \pm 4,224$ ) and the active group ( $H t, B: 45.00 \pm 0.63$ vs. $A: 47.00 \pm 0.01 ; R B C, B: 477 \pm 30$ vs. $A: 559 \pm 37 ; L, B: 6,418 \pm 3,557$ vs. A: 6,632 $\pm 4,460)$. Conclusion: Differences were found only in concentric actions between groups. Additionally, there were no relationships found in hematological parameters between groups.
\end{abstract}

Keywords: muscle fatigue; muscle, skeletal; muscle strength; physiology.

\section{RESUMO}

Introdução: A fadiga muscular durante as contrações musculares voluntárias é um fenômeno complexo e multifatorial associado a alterações centrais e adaptações do sistema neuromuscular. Objetivo: O objetivo deste estudo é analisar as alterações do pico de torque e dos parâmetros hematológicos em indivíduos saudáveis ativos e inativos depois de realizar um protocolo de fadiga muscular. Métodos: Vinte e um adultos saudáveis do sexo masculino realizaram um protocolo de fadiga muscular (10 séries, 10 repetições de extensão do joelho a 75\% do torque isométrico máximo (TIM) a $120^{\text {os-1 }}$ e 40 segundos de repouso). Hematócrito (Ht), glóbulos vermelhos (GV) e leucócitos (L) foram analisados antes (A) e depois (D) do teste de fadiga. Resultados: O grupo inativo apresentou deterioração apenas na ação muscular concêntrica (-41 $\pm 4 \%$ ) com relação ao grupo ativo (-23 $\pm 3 \%)$. Não foram encontradas diferenças nos parâmetros hematológicos no grupo inativo ( $H t, A: 45,00 \pm 0,01$ vs. D: 47,00 $\pm 0,01 ; G V, A: 442 \pm 40$ vs. D: $487 \pm 41 ; L, A$ : $7.565 \pm 2.878$ vs. D: $8.015 \pm 4.224$ ) e no grupo ativo ( $H t, A: 45,00 \pm 0,63$ vs. D: $47,00 \pm 0,01 ; G V, A: 477 \pm 30$ vs. D: $559 \pm$ 37: L, A: $6.418 \pm 3.557$ vs. D: $6.632 \pm 4.460)$. Conclusão: Foram encontradas diferenças apenas em ações concêntricas entre os grupos. Além disso, não foram encontradas relações quanto aos parâmetros hematológicos entre os grupos.

Descritores: fadiga muscular; músculo esquelético; força muscular; fisiologia.

\section{RESUMEN}

Introducción: La fatiga muscular durante las contracciones musculares voluntarias es un fenómeno complejo y multifactorial asociado con cambios centrales y adaptaciones del sistema neuromuscular. Objetivo: El objetivo de este estudio es analizar los cambios del par máximo y los parámetros hematológicos en sujetos sanos activos e inactivos después de un protocolo de fatiga muscular. Métodos: Veintiún adultos sanos del sexo masculino realizaron un protocolo de fatiga muscular (10 series, 10 repeticiones de extensión de la rodilla en el 75\% del par isométrico máximo (PIM) a $120^{\text {ss- }-1}$ y 40 segundos de descanso). Hematocrito (Ht), glóbulos rojos (GR) y leucocitos (L) fueron evaluados antes (A) y después (D) de la prueba de fatiga. Resultados: El grupo inactivo presentó deterioro sólo en la acción muscular concéntrica $(-41 \pm 4 \%)$ con respecto al grupo activo $(-23 \pm 3 \%)$. No se encontraron diferencias en los parámetros hematológicos en el grupo inactivo ( $H t, A: 45,00 \pm 0.01$ vs. D: 47,00 $\pm 0,01 ; G R, A: 442 \pm 40$ vs. D: $487 \pm 41 ; L, A: 7.565 \pm$ 2.878 vs. D: $8.015 \pm 4.224$ ) y en el grupo activo ( $H t, A: 45,00 \pm 0,63$ vs. A: $47,00 \pm 0,01 ; G R, A: 477 \pm 30$ vs. D: $559 \pm 37 ; L$, A: $6.418 \pm 3.557$ vs. D: $6.632 \pm 4.460)$. Conclusión: Se encontraron diferencias sólo en las acciones concéntricas entre los grupos. Además, no hubo relaciones con respecto a los parámetros hematológicos entre los grupos.

Descriptores: fatiga muscular; músculo esquelético; fuerza muscular; fisiología. 


\section{INTRODUCTION}

Conceptually, muscle fatigue corresponds to an inability to maintain skeletal muscle strength levels for a certain period of time' ${ }^{1}$. Studies ${ }^{2}$ investigating muscle fatigue have been published that consider the multiple facets of the associated fatigue mechanisms, with a view to understanding the fatigue process. Some of the mechanisms involved in the fatigue process ${ }^{2}$, include changes in electromyography ${ }^{3}$, mechanical alterations ${ }^{4}$, changes in blood biochemistry ${ }^{5}$ have received much attention. However, research related to hematological change is still inconclusive ${ }^{6}$. Some studies ${ }^{7}$ have outlined this research limitation during studies investigating biochemical associations and fatigue profiles following exercise.

In addition, fatigue profiles of individuals with different levels of fitness and levels of physical activity have received little attention in the scientific community. Knowledge about the relationship between physical activity as a risk factor for chronic degenerative disease is already well established in the literature ${ }^{8}$. The level and intensity of physical activity has been recognized as a component that influences muscle performance ${ }^{9,10}$ by promoting force development and endurance. However, information relating to the mechanisms influencing performance when this variable is considered remains inconclusive.

Therefore, considering the lack of information in this area, especially the relationship between the level of physical activity and changes in hematological parameters, the objective of this study, was to investigate any changes in force development following a fatigue protocol. A secondary objective was to consider muscle action and changes in hematological parameters of active and inactive individuals undergoing a specific muscle fatigue protocol.

\section{MATERIALS AND METHODS}

Following approval by the Research Ethics Committee of the São Judas Tadeu University (number 786.06), twenty male adults aged $\geq 18$ years and physically independent signed an Informed Consent form to participate voluntarily in this study. The International Physical Activity Questionnaire (IPAQ) - short version was used to estimate the level of physical activity conform previously publication of our group ${ }^{10}$. Questions were based on the level of physical activity performed weekly. The questions explored frequency and duration of exercise, including moderate walking, vigorous exercise and time spent sitting down. Subjects were considered active if they reached or exceeded 150 minutes of physical activity per week. Subjects who did not reach 150 minutes per week were classified as inactive. Classifications were based on the guidelines outlined by the World Health Organization. Subjects with diabetes mellitus, current smokers, individuals with musculoskeletal injuries and diagnosed clinical case pathologies and/or cardiovascular changes confirmed by medical evaluation, were excluded from the study.

\section{Anthropometric measurements}

Anthropometric assessment was performed following the model previously outlined by our group ${ }^{11,12}$. Briefly, height was measured with a Cardiomed stadiometer (WCS model), with a $115 / 120 \mathrm{~cm}$ range. The measurement was performed with the cursor placed at a $90^{\circ}$ angle with the scale in the upright position, and feet placed together in contact with the stadiometer. Subjects were instructed to hold their breath and keep the head parallel to the ground. Weight was measured with a calibrated electronic scale (Filizola - Personal Line Model 150), with a 100 grams range, and maximum capacity of $150 \mathrm{~kg}$. Body mass index (BMI) was calculated and recorded from the equation weight/height'.

\section{Fatigue induction protocol}

The completion of the dynamic fatigue protocol followed the model used of our group ${ }^{10}$. Briefly, all subjects attended the Laboratory on four occasions to perform an Isokinetic evaluation protocol using a Biodex System 3 (Biodex, Inc.,Shirley, NY). On the first day, the subjects signed consent forms and completed the IPAQ. On the second day, anthropometric data (height, and weight) was evaluated. On the third day, the subjects were placed on the Isokinetic Dynamometer in a comfortable, upright, seated position for familiarization procedures. Straps were used to fix the thigh, pelvis, and trunk to prevent extraneous body movement. The axis of the dynamometer was aligned with the axis of right knee joint rotation. Arms were placed across the chest with hands grasping the straps. All subjects performed eight repetitions of sub maximum concentric/eccentric knee extension/flexion at 120os1. The knee joint range of motion was 90 to $10^{\circ}$ of knee flexion. The calibration of the Isokinetic Dynamometer was performed according to the specifications of the manufacturer before each test, and finally, on the fourth day the fatigue protocol was performed. All testing and experimental procedures were performed at the same time of day to exclude diurnal variation. The fatigue protocols were performed at an intensity of $70 \%$ of maximum isometric contraction, which was determined on the third day.

\section{Evaluation of hematological indicators}

To establish hematological changes, blood was collected with a $5 \mathrm{ml}$ syringe using methodologies outlined previously ${ }^{10}$. Subsequently, the blood was transferred into tubes containing EDTA and kept in motion to avoid coagulation. The hematocrits were analyzed with the microhematocrit technique, which consists of collecting blood in a microcapillary tube of up to $3 / 4$ of its capacity, sealing one end with plasticine, then centrifuging for five minutes at 10,000 rpm in a microcentrifuge. The reading was recorded from a table for hematocrit, considering between 40 and $50 \%$ of red blood cells (RBC) as normal values. For the RBC count, $20 \mathrm{ml}$ of blood was diluted in $5 \mathrm{ml}$ of citrate formaldehyde, with subsequent counting in a Neubauer chamber. For the establishment of leukocyte count, the same amount of blood was diluted in 4000 l Turk, with subsequent counting in a Neubauer chamber. Cells were counted in a manual counter (model SYSMEX-SF- 3000) in the specific areas for each cell type with appropriate calculations of dilutions performed. A slide containing a blood smear was used to verify the morphology and the usefulness of cells. Smears were made by dragging a drop of blood by contact with another slide, and the material was placed to drynaturally. After complete drying, the slides were subjected to the Fast Panoptic method, with a methanol bath for five seconds for fixation, eosin for five seconds, and ten seconds in Methylene Blue for coloring. Then, slides were washed with deionized water and observed under an optical microscope.

\section{Statistical analysis}

The analyses were performed using the SPSS for Windows (version 12.0; SPSS, Chicago, IL, USA). The D'Agostino-Pearson test was used for data normalization. For comparison group analysis was used the Student's t test or two-way ANOVA for repeated measures, followed by a post- hoc Bonferroni test as needed. Data are expressed as mean and standard error of the mean, and the significance level was set at $p<0.05$.

\section{RESULTS}

After analyzing the IPAQ questionnaire, seminal time spent on physical activity of the inactive group corresponded to $121 \pm 36$ minutes, which was significantly lower $(p=0.001)$ than the active group (657 \pm $267 \mathrm{~min}$ ). In relation to anthropometric parameters no differences were found between groups, as shown in Table 1.

After application of the fatigue-inducing protocol, significant differences $(p<0.01)$ in peak torque were found for both groups after the second set, both for the concentric (Figure 1A) and eccentric muscle action (Figure 1B). Significant differences $(p<0.001)$ in the force-repetition 
curve slope were found only in the eccentric peak torque between groups (active: $-6.30 \pm 0.61$, inactive: $-9.55 \pm 12: 29 ; \mathrm{Nm} /$ series). No difference was found in the eccentric peak torque between active $(-13.24 \pm 0.62 \mathrm{Nm}$ / series) and inactive groups (-14.28 $\pm 0.77 \mathrm{Nm} /$ series).

Additionally, a significant percentage reduction ( $p<0.001)$ was found after ten sets at torque maintenance of both groups in both the concentric (active: $-23 \pm 2$, inactive: $-41 \pm 4 ; \%$ ) and the eccentric (active: $-41 \pm 3$, inactive: $-46 \pm 3$; \%) muscular action as shown in Figures $1 \mathrm{C}$ and 1D. Differences between the percentage of maintenance of muscle strength in concentric peak torque are observed from set 5 between inactive groups (set 5: $-19 \pm 3$, set 6: $-25 \pm 3$; set 7: $-27 \pm 3$, set $8:-31 \pm$ 4, set 9: $-34 \pm 4$, set $10:-41 \pm 4 ; \%$ ) and active groups (set 5 : $-12 \pm 2$, set 6: $-15 \pm 3$, set $7:-17 \pm 3$, set $8:-19 \pm 3$, set 9 : $-20 \pm 3$, set $10:-23 \pm 3 ; \%)$.

Table 2 presents the hematological parameters. In spite of increases in all analyzed parameters, no significant difference was established between groups, before and following the fatigue protocol.

Table 1. Anthropometric parameters.

\begin{tabular}{c|c|c|c}
\hline & Inactive & Active & Significance \\
\hline Age $($ years $)$ & $26 \pm 6$ & $28 \pm 7$ & $p=0.636$ \\
\hline Height $(\mathrm{cm})$ & $1.74 \pm 1.0$ & $1.81 \pm 1.0$ & $p=0.057$ \\
\hline Weight $(\mathrm{kg})$ & $80 \pm 13$ & $87 \pm 18$ & $p=0.316$ \\
\hline BMl $\left(\mathrm{kg} / \mathrm{cm}^{2}\right)$ & $26 \pm 3$ & $26 \pm 4$ & $p=0.991$ \\
\hline
\end{tabular}

Values expressed in mean \pm standard deviation.

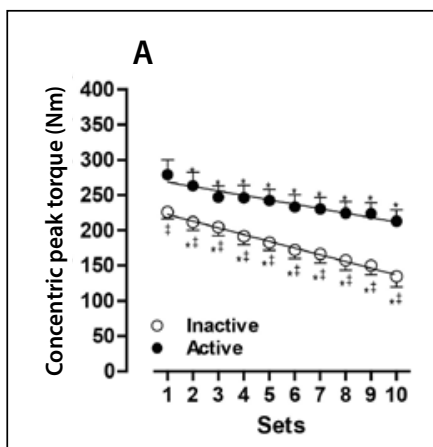

C

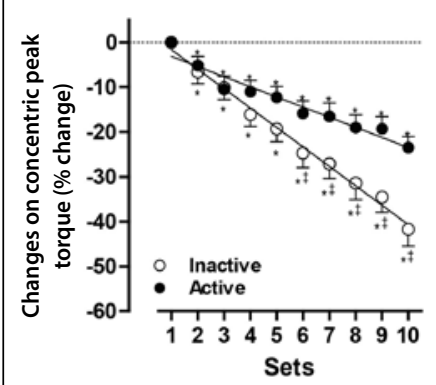

*indicates statistically significant differences $(p<0.01)$ of the first sets.

findicates statistically significant differences between groups.

Figure 1. Values expressed as mean \pm standard deviation of concentric peak torque (Panel A), Eccentric peak torque (Panel B), Changes (\%) of concentric (Panel C) and eccentric (Panel D) peak torque during the muscle fatigue induction protocol of inactive (o) and active subjects $(\bullet)$

Table 2. Hematological parameters.

\begin{tabular}{|c|c|c|c|c|c|c|}
\hline & \multicolumn{3}{|c|}{ Inactive } & \multicolumn{3}{|c|}{ Active } \\
\hline & Before & After & $\%$ & Before & After & $\%$ \\
\hline Hematocrit (\%) & $45.00 \pm 0.01$ & $47.00 \pm 0.01$ & $4 \pm 1$ & $45.00 \pm 0.63$ & $47.00 \pm 0.01$ & $5 \pm 2$ \\
\hline $\begin{array}{c}\text { Red blood cells } \\
\text { (count) }\end{array}$ & $442 \pm 40$ & $487 \pm 41$ & $9 \pm 4$ & $477 \pm 30$ & $559 \pm 37$ & $10 \pm 8$ \\
\hline $\begin{array}{c}\text { Leukocyte } \\
\text { (cells/ } \mu \mathrm{L})\end{array}$ & $7565 \pm 2878$ & $8015 \pm 4224$ & $9 \pm 58$ & $6418 \pm 3557$ & $6632 \pm 4460$ & $1 \pm 18$ \\
\hline
\end{tabular}

\section{DISCUSSION}

The reduction in muscle performance has been the focus of numerous studies ${ }^{13,14}$ especially when considering the mechanisms involved in its development. When we refer to tension development, our data agree with the study previously published ${ }^{10}$ by our group, demonstrating that active individuals have higher fatigue resistance than inactive individuals. Taking into account the responses of different muscle actions, our data indicate a reduction of torque capacity in both groups in eccentric and concentric action. However, only significant differences were found between groups when comparing concentric actions.

The reduction in muscular strength (peripheral) is related to several mechanisms. These include: increase in concentrations of ADP, Pi, AMP, $\mathrm{Ca}^{2+}$ and $\mathrm{H}^{+}$, resulting in changes in sarcoplasmic reticulum function to release and recapture $\mathrm{Ca}^{2+}$, with decreased concentrations of phosphocreatine and glycogen. Also, reduced velocity of conduction and amplitude of action potentials due to the potassium flow, changes in threshold of excitability of muscle fibers for action potentials, and a delayed relaxation phase after a contractile movement are contributory factors $^{13,15}$. To our knowledge only a few studies ${ }^{7,9}$ investigated the differences between specific groups in response to fatigue.

Differences between muscle actions have already been investigated in the literature ${ }^{16-21}$ demonstrating greater impairment in concentric muscle activation $3,19,20$, increased metabolic burden evaluated by lactate concentration ${ }^{3}$ in concentric muscle actions and of elastic components specifically in the titin protein ${ }^{16,21}$ have been recognized as indicators of this difference.

Considering hematological changes and physical exercise, many of the available studies have used horses ${ }^{22}$. To our knowledge, there are few studies ${ }^{23}$ that investigated the effects of fatigue on hematological parameters in humans. In 1977 Novosadová24 evaluated changes between rest and exercise and found no difference between the conditions. However, studies found significant changes in parameters such as blood viscosity $^{7}$ and leukocyte profile ${ }^{23}$

The proportion of blood represented by red blood cells is called hematocrit. For adult men and women, the mean hematocrit concentration corresponds to 42 and 38 respectively, and these values can vary considering the presence of anemia, degree of bodily activity, and the altitude at which the person resides. In our study, the hematocrit-independent concentration of the groups has not changes significantly (Table 2) following the fatigue protocol. Additionally, the values found in our study were similar to others ${ }^{7}$. Thus, it is possible to consider the relationship between the variation in hematocrit concentration and the osmotic balance and cell hydration, which are characteristics present in predominantly anaerobic exercises ${ }^{7}$. Anaerobic performance demonstrates little change in water content and concomitant changes in blood viscosity when compared to aerobic exercises ${ }^{25}$.

Such changes in viscosity with concomitant changes in red blood cells may contribute to alterations in the oxygen transport system but these alterations are found mainly in aerobic exercise ${ }^{25}$. The primary function of red blood cells (erythrocytes) is the transportation of hemoglobin that carries oxygen from the lungs to the tissues. When free in the plasma of human beings, about $3 \%$ of total hemoglobin overflows through the capillary membrane into the interstitial space or through the kidney glomerular membrane to the glomerular filtrate. This happens each time that blood passes through the capillaries. Thus, hemoglobin should remain within the red blood cells to perform its functions effectively.

Red blood cells have other functions besides hemoglobin transport. For example, they contain a large amount of carbonic anhydrase, an enzyme that catalyzes the reversible reaction between carbon dioxide and water to form carbonic acid, increasing by thousands of times the 
velocity of this reaction ${ }^{26}$. The velocity of this reaction helps transport large quantities of $\mathrm{CO}_{2}$ in the form of bicarbonate ions from the tissues to lungs, where it is converted to $\mathrm{CO}_{2}$ and eliminated to the atmosphere as a product of body metabolism ${ }^{26}$. The hemoglobin in the cells is considered an excellent basic acid buffer, and responsible for most of the blood acid-base buffering capacity.

The figures for red blood cells in the present study did not differ between active and inactive individuals (Table 2), and were similar to other studies in humans ${ }^{27}$ and animals ${ }^{28}$. However, values remain indifferent when referring to anaerobic exercises, especially when performed close to exhaustion.

When referring to leukocyte concentration, no differences were noted after completion of the fatigue protocol in both groups (Table 2). Leukocytes are formed partly in the bone marrow (granulocytes, monocytes and some lymphocytes), and partly in the lymphatic tissue (lymphocytes and plasma cells). The leukocyte action is directed at areas of severe infection and inflammation, promoting fast and powerful defense mechanisms against infectious agents.

The increased concentration of leukocytes is closely related to increased inflammation and serious infections ${ }^{29}$. When referring to physical exercise, especially depending on intensity and duration several Dias et $a l .^{30}$ showed increase, decrease or maintenance of leukocyte values. Although not statistically different, the leukocyte values of inactive individuals were higher than those of active individuals, possibly as a result of the immune protection promoted by regular practice of physical activity $^{30}$. Studies $23,27,29$ have showed that in acute situations, the practice of strenuous exercise can increase the inflammatory process allowing increased leukocyte content. Considering data from our study, we did not demonstrate significant increases in leukocyte content, which may indicate absence of inflammation following the fatigue protocol. However, the values in this study were similar to other ${ }^{30}$. Additionally, the increase of lymphocytes is controlled by catecholamine concentration, particularly in activities of short duration ${ }^{31}$.

\section{CONCLUSION}

In conclusion, the neuromuscular response differs when analyzing eccentric and concentric actions. However, the concentric action had more impact on the development of muscle strength during the fatigue protocol, which was different between active and inactive individuals. Additionally, no hematological changes were found following the fatigue protocol in both groups.

\section{ACKNOWLEDGEMENT}

The authors thank CAPES (Coordenação de Aperfeiçoamento de Pessoal de Nível Superior) fellowships addressed to Suzuki FS. The fund providers had no role in decision to publish and preparation of the paper.

All authors declare no potential conflict of interest related to this article.

AUTHORS' CONTRIBUTIONS: Each author contributed individually and significantly to the development of the manuscript. ACA (0000-0002-9644-5068)* ALE (00000002-4941-6475)*, AFJ (0000-0001-8069-2366)*, MRP (0000-0003-1857-6924)* and AJS (000-0001-9591-3547)*, performed the laboratory procedures, as well as recruiting the volunteers, conducting the anthropometric measurements and filling out the questionnaires, and training volunteers in the use of the Isokinetic Dynamometer. The treatment of the signs obtained and evaluated the data from the statistical analysis was done by MMK (0000-0002-2406-4450)*, FP (0000-0002-7901-3351)*, AJS (00000002-5407-8183)*, RAFP, (000-0002-5513-3973)*, SMS (0000-0003-0990-9125)*, The revision of the manuscript and contributions to the intellectual concept of the study were provided and the main contributors to the writing of the manuscript by FSS (0000-0002-4745-5788)*, DB (0000-0002-4320-4615)*, JSB (000-0002-9846-4916)*, DSB (0000-0003-3993-8277)*. *ORCID (Open Researcher and Contributor ID).

\section{REFERENCES}

1. Enoka RM. Neuromechanics of human movement. 4th ed. Champaign, IL: Human Kinetics; 2008

2. Abbiss $C R$, Laursen PB. Models to explain fatigue during prolonged endurance cycling. Sport Med. 2005:35(10):865-98.

3. Gonzalez-Izal M, Cadore EL, Izquierdo M. Muscle conduction velocity, surface electromyography variables, and echo intensity during concentric and eccentric fatigue. Muscle Nerve. 2014;49(3):389-97.

4. Katsiaras A, Newman AB, Kriska A, Brach J, Krishnaswami S, Feingold E, et al. Skeletal muscle fatigue, strength, and quality in the elderly: the Health ABC Study. J Appl Physiol. 2005;99(1):210-6.

5. Bertuzzi RC de M, Silva AEL, Abad CCC, Pires F de O. Lactate metabolism: a review on bioenergetics and muscle fatigue. Rev Bras Cineantropom Desempenho Hum. 2009;11(2):226-34.

6. Olkoski MM, Fuke K, Matheus SC, Soares FAA, Portella R, Da Rosa EJF, et al. Physical and biochemical responses to training performed in and out of the water in indoor soccer players. Motriz. 2013;19(2):432-40.

7. Petrício AIM, Porto M, Burini RC. Changing in hemodynamics, basic acid equilibrium and enzymatics in the exhaustive exercise with weights. Ativ Fís Saúde; 2001;6(3):17-26.

8. González-Gross M, Meléndez A. Sedentarism, active lifestyle and sport: Impact on health and obesity prevention. Nutr Hosp. 2013;28(Suppl 5):89-98.

9. Bogdanis GC. Effects of physical activity and inactivity on muscle fatigue. Front Physiol. 2012;3(3):1-15

10. Suzuki FS, Kalytczak MM, Casarin CAS, Serra AJ, Evangelista AL, Marchetti PH, et al. Physical activity level does not influence the neuromuscular fatigue in adults. Rev Bras Med Esporte. 2016;22(2):97-101.

11. Serra AJ, Amaral AM, Rica RL, Barbieri NP, Reis Junior D, Silva Junior JA, et al. Determination of body density by generalized equations: easiness and simplification in the method. ConScientiae Saúde. 2009:8(1):19-24

12. Martins A, Ceschini F, Battazza R, Rodriguez D, Allegretti G, Bocalini D, et al. A Low-volume weight training protocol reduces abdominal fat and increases muscle strength in 12 weeks. J Exerc Physiol. 2016;19(1):96-106.

13. Hunter SK, Critchlow A, Enoka RM. Muscle endurance is greater for old men compared with strength-matched young men. J Appl Physiol. 2005;99(3):890-7.

14. Corvino RB, Caputo F, de Oliveira AC, Greco CC, Denadai BS. Rate of force development in different muscle contraction velocities. Rev Bras Med Esporte. 2009;15(6):428-31.

15. Hunter SK. Sex differences and mechanisms of task-specific muscle fatigue. Exerc Sport Sci Rev. 2009;37(3):113-22.

16. Ide BN, Dechechi CJ, Lopes CR, Brenzikofer R, Macedo DV. Eccentric muscle movements - Why Generate more power? Why Generate more trauma? Rev Bras Prescr Fisiol Exerc. 2011;5(25):61-8.
17. Kawakami Y, Kanehisa H, Ikegawa S, Fukunaga T. Concentric and eccentric muscle strength before, during and after fatigue in 13 year-old boys. Eur J Appl Physiol Occup Physiol. 1993;67(2):121-4.

18. Mullaney MJ, McHugh MP. Concentric and eccentric muscle fatigue of the shoulder rotators. Int $J$ Sports Med. 2006;27(9):725-9

19. Pasquet B, Carpentier A, Duchateau J, Hainaut K. Muscle fatique during concentric and eccentric contractions. Muscle Nerve. 2000;23(11):1727-35.

20. Tesch PA, Dudley GA, Duvoisin MR, Hather BM, Harris RT. Force and EMG signal patterns during repeated bouts of concentric or eccentric muscle actions. Acta Physiol Scand. 1990;138(3):263-71.

21. Trappe TA, Carrithers JA, White F, Lambert CP, Evans WJ, Dennis RA. Titin and nebulin content in human skeletal muscle following eccentric resistance exercise. Muscle Nerve. 2002;25(2):289-92.

22. Veiga APM, Lopes STDA, Franciscato C, Oliveira LSS De, Merini LP. Hematological values, plasma protein and fibrinogen of criollo horse - their variation with sex, age and management. Acta Sci Vet. 2006;34(10):275-9.

23. Prestes J, Frollini AB, Guereschi M, Dias R, Donatto FF. Effects of two acute exercise sessions performed in the same day in different intensities on total leukocytes counting, circulating and tissue lymphocytes. Rev Bras Ciênc Saúde. 2007;3(11):27-33.

24. Novosadová J. The changes in hematocrit, hemoglobin, plasma volume and proteins during and after different types of exercise. Eur J Appl Physiol Occup Physiol. 1977;36(3):223-30.

25. Ferreira FG, Alves K, Costa NMB, Santana ÂMC, Marins JCB. Effect of physical conditioning level and oral hydration on hydric homeostasis in aerobic exercise. Rev Bras Med Esporte. 2010;16(3):166-70.

26. Ribeiro F, Campbell CSG, Mendes G, Arsa G, Moreira SR, da Silva FM, et al. Exercise lowers blood pressure in university professors during subsequent teaching and sleeping hours. Int J Gen Med. 2011;4:711-6.

27. Ellwanger RB, Brentano MA, Kruel LFM. The effect of different velocities of strength training in indirect markers of muscle damage. Rev Bras Educ Fís Esp. 2007;21(4):259-70.

28. Leandro C, Nascimento E, Manhães-de-Castro R, Célia MMB. Physical exercise and immune system: mechanisms and integra- tion processes. Rev Port Cien Desp. 2002;2(5):80-90

29. Foschini D, Prestes J, Charro MA. Relationship between physical exercise, muscle damage and delayed-onset muscle soreness. Rev Bras Cineantropom Desempenho Hum. 2007;9(1):101-6.

30. Dias R, Frollini AB, Prestes J, Teixeira LFM, Cereja DMP, Baganha RJ, et al. Strength exercise and immunologica parameters: leukocytes counting, inflammation and regeneration. Rev Bras Ciênc Mov. 2008;16(3):100-7.

31. Minetto M, Rainoldi A, Gazzoni M, Terzolo M, Borrione P, Termine A, et al. Differential responses of serum and salivary interleukin-6 to acute strenuous exercise. Eur J Appl Physiol. 2005;93(5-6):679-86. 